\title{
Goue jubileum van metrisering: 50 jaar sedert die jaart
}

Outeurs:

Cobus Vermeulen ${ }^{\mathrm{a}}$

Jannie Rossouw ${ }^{b}$

Affiliasies:

aDepartement Ekonomie,

Universiteit van Suid-Afrika,

Posbus 392, Unisa, 0003.

Suid-Afrika

bWits Besigheidskool

Universiteit van die

Witwatersrand, Posbus 98,

Wits, Johannesburg, 2050,

Suid-Afrika

Korresponderende outeur:

Cobus Vermeulen

E-pos: vermejc@unisa.ac.za

\section{ORCID}

C Vermeulen

https://orcid.org/0000-

0002-1385-1838

J Rossouw

https://orcid.org/0000

0001-6200-1621

\section{Datums:}

Ontvang: $\quad 23 / 11 / 20$

Aanvaar: $\quad 06 / 04 / 21$

Gepubliseer: 31/05/21

Hoe om hierdie artikel aan te haal:

Cobus Vermeulen,

Jannie Rossouw, Goue

jubileum van metrisering:

50 jaar sedert die jaart,

Suid-Afrikaanse Tydskrif

vir Natuurwetenskap en

Tegnologie 40(1) (2021).

https://doi.org/10.36303/

SATNT.2021.40.1.805

\section{Kopiereg:}

(C) 2021. Authors.

Licensee: Die Suid-

Afrikaanse Akademie vir

Wetenskap en Kuns.

Hierdie werk is onder

die Creative Commons

Attribution License

gelisensieer.
Die Republiek van Suid-Afrika het op 1 April 1971 begin met die praktiese implementering van die omskakelingsproses vir die gebruik van die metrieke stelsel van volume, mates, massaeenhede, temperatuur en so meer. Met die aanvaarding van metrieke afstandmates en spoedmeting op 1 April 1971 is 'n omskakelingstydperk van enkele jare ingelei. Die belangrike stap om afstand en spoed te metriseer het nie slegs Suid-Afrika op die pad na volle metrisering geplaas nie, maar het ook die proses baie sigbaar vir die publiek gemaak.

Metrisering het die imperiale stelsel, wat voorheen in gebruik was, vervang. Mates soos jaart (tree) en voet is met meter en sentimeter vervang. Vir volume is liter, eerder as gelling en pint, in gebruik geneem en kilogram en gram, eerder as pond en ons, is as massaeenhede aanvaar. Celsius, eerder as Fahrenheit, is vir temperatuurmeting aanvaar. Die komma is ook aanvaar om desimale waardes aan te dui, teenoor die punt wat voorheen gebruik is. Die voordele van metrieke mates is die desimale grondslag waarop dit gegrond is en die standaardisering van eenhede wat internasionale handel bevorder.

Hierdie artikel toon dat Suid-Afrika suksesvol was in die volledige afhandeling van metrisering, teenoor sekere ander lande wat die proses aangepak het maar tot dusver nooit volledig voltooi het nie, of selfs nie aangepak het nie. Hierdie artikel toon dat volledige afhandeling van metrisering die korrekte strategie is, soos in Suid-Afrika die geval was.

Trefwoorde: imperiale mates, metrieke stelsel, metrisering, Suid-Afrika

Golden jubilee of metrication: 50 years since the yard: The Republic of South Africa commenced with the introduction of the usage of a metric system of volume, measurements, mass, temperature, and the like on 1 April 1971. From that date the measurement of distance and speed were recorded in metric measurement, which placed South Africa on a path to full metrication over a number of subsequent years. The adoption of metric measurement for distance and speed also focused the attention of the public vividly on the metrication process that was rolled out fully over a number of subsequent years after 1 April 1971.

Full conversion to the metric system was completed in a reasonable period of time. This system replaced the imperial system previously in use. Measurements such as yard and feet were replaced with metre and centimetre. In the case of volume, gallon and pint were replaced with litre, and kilogram and gram replaced pound and ounce as measurements of mass. Celsius replaced Fahrenheit for measuring temperature. The use of the comma to indicate decimal places was also introduced. The advantages of the metric system are its foundation in the decimal system and standardisation of units which promotes international trade.

This article shows that South Africa was successful in the introduction and completion of metrication, compared to several other countries that embarked on metrication but never completed the process, or countries that did not even commence with a metrication process. This paper shows that South Africa adopted the appropriate strategy.

Keywords: imperial measurements, metric system, metrication, South Africa

1 Die menings en gevolgtrekkings in hierdie artikel weerspieël die outeurs se standpunte en moet op geen wyse aan die universiteite toegeskryf word nie. Ons is dank verskuldig aan twee anonieme eweknie-beoordelaars vir hul waardevolle kommentaar en aanbevelings. 


\section{Inleiding}

Die Republiek van Suid-Afrika het op 1 April 1971 begin met die praktiese implementering van die omskakelingsproses vir die gebruik van die metrieke stelsel van volume, mates, massaeenhede, temperatuur en so meer. Die aanvaarding van metrieke afstandmates en spoedmeting op 1 April 1971 (Mackey en Roodt, 2002) het 'n omskakelingstydperk van enkele jare ingelei. Die belangrike stap om afstand en spoed te metriseer het nie slegs Suid-Afrika op die pad na volle metrisering geplaas nie, maar het ook die proses baie sigbaar vir die publiek gemaak. Die goue jubileum van die aanvang van metrisering is dus op 1 April 2021. Die metrieke stelsel het die imperiale stelsel, wat Suid-Afrika voorheen gebruik het, vervang. Dit was ' $n$ ingrypende verandering nadat Suid-Afrika sedert die 1800s grootliks imperiale mates gebruik het.

Met die aanvaarding van die metrieke stelsel is mates soos jaart (tree) en voet met meter en sentimeter vervang, terwyl liter, eerder as gelling en pint, vir volume in gebruik geneem is, en kilogram en gram, eerder as pond en ons, as massaeenhede aanvaar is. Celsius, eerder as Fahrenheit, is vir temperatuurmeting aanvaar. Die komma is ook aanvaar om desimale waardes aan te dui, teenoor die punt wat voorheen gebruik is. Die groot voordeel van metrieke mates is die desimale grondslag waarop dit gegrond is, teenoor die wye reeks van eenhede wat in ' $n$ imperiale stelsel gebruik word. In die imperiale stelsel is daar byvoorbeeld drie voet in 'n jaart, of 32 onse in 'n pond. ' $n$ Verdere voordeel is die internasionale standaardisering van mates, wat tot 'n groot mate internasionale handel en vervaardiging ondersteun en bevorder.

Hierdie artikel toets eerstens die hipotese dat Suid-Afrika suksesvol en volledig gemetriseer het. Hierteenoor het sekere lande die proses aangepak maar nooit volledig voltooi nie, of selfs nooit aangepak nie. Hierdie artikel gebruik Chalupsky et al. (1974:116-122) se beoordelingstruktuur in die oorweging van die sukses van metriseringsprosesse, naamlik:

- Grootskaalse betrokkenheid van alle belanghebbendes in die gemeenskap in die beplanning van 'n metrieke oorskakeling.

- Verbintenis deur die regering tot beleidsbesluite en vaste tydskedules.

- Deurlopende kommunikasie en koördinasie vanaf owerheidsweë.

Chalupsky et al. (1974:53) beskryf hierdie beoordelingstruktuur binne die hoekstene van " ... the four " $c$ 's" of conversion - consultation, cooperation, coordination and communication".

Weens die logika van die metrieke stelsel teenoor die imperiale stelsel en die aktiewe rol van die Suid-Afrikaanse regering was die omskakelingsproses betreklik soomloos. Gevolglik is akademiese literatuurbronne oor die onder- werp beperk. Tweedens dra hierdie artikel dus tot die akademiese literatuur by deur die suksesfaktore van die Suid-Afrikaanse metriseringsproses uit te lig en te vergelyk met die ervaring van prominente lande wat nie suksesvol gemetriseer het nie. Verder is plaaslike literatuur soos Ball (2016 en 2018), Erasmus (1960) en Vlietstra (S.a.) in die ontleding in hierdie artikel gebruik, terwyl internasionale literatuur soos Laner (1978) en Chalupsky et al. (1974) ook gebruik is in die teks wat volg.

Die res van hierdie artikel is soos volg gestruktureer: Afdeling 2 gee ' $n$ kort historiese oorsig oor die imperiale en metrieke stelsels, en die geskiedenis van volume, mate, massaeenhede en so meer wat voorheen in Suid-Afrika gebruik is. In Afdeling 3 word die omskakeling van die imperiale na die metrieke stelsel in Suid-Afrika bespreek. Afdeling 4 lig metriseringsprobleme in sekere ander lande toe. Hierdie afdeling vergelyk ook kortliks die SuidAfrikaanse ervaring met dié van die VSA en VK, as onderskeidelik voorbeelde van nie-gemetriseerde en gedeeltelikgemetriseerde lande. Die gevolgtrekkings volg in Afdeling 5 .

\section{Geskiedkundige oorsig Imperiale stelsel}

Die imperiale stelsel het in Engeland ontwikkel uit die duisende Arabiese, Romeinse, Keltiese en Anglo-Saksiese meeteenhede in gebruik tydens die Middeleeue (Hosch, 2010, Chaney, 1897). In 1324, onder Koning Edward II, is bepaal dat drie ronde, droë gortpitte (barleycorns) saam een duim ("inch") sou vorm, 12 duim een voet, en drie voet een jaart (Chaney, 1897). Die Winchester Stelsel het vervolgens in die laat $15^{\text {de }}$ eeu, onder Koning Henry VII, begin ontwikkel en was amptelik in gebruik tydens 1588 - 1824 (Chaney, 1897).

Die Britse imperiale stelsel is formeel gedefinieer deur die eerste Weights and Measures Act van 1824 (VK, 1824) om die argaïese Winchester Stelsel te vervang, en is gevolglik deur lande in die Britse ryk gebruik. Die imperiale stelsel is gebaseer op twee eenhede, naamlik die jaart ("yard") as eenheid van lengte en die pond ("pound") as eenheid van massa (Chaney, 1897). Die imperiale stelsel gebruik verder rekeneenhede of mates wat na liggaamsdele (bv. duime of voete), ander alledaagse items (bv. "stone") wat bloot weens konvensie aanvaar is, of prototipe stawe, pale of artefakte (bv. 'n jaartstok), verwys.

Chaney (1897:21) verwys na die imperiale standaarde as "material or arbitrary standards constructed by hand", maar sonder ' $n$ anker of verwysing na natuurlike of fisiese standaarde. Sodanige afwesigheid van 'n fisiese standaard het egter teenstrydighede tot gevolg gehad, en het ook die akkuraatheid van wetenskaplike navorsing in twyfel getrek, wat bygedra het tot die ontwikkeling van die metrieke stelsel (Chaney, 1897). 


\section{Metrieke stelsel}

Aldus Ball (2018) is die eerste voorspraak vir 'n universele desimale stelsel reeds so ver terug as 1668 deur John Wilkins in Engeland gemaak. Volgens Wilkins sou 'n desimale stelsel die gebruik van verskillende meet- en massastelsels deur Europa uitskakel en met 'n standaardstelsel vervang (Ball, 2018). Na Wilkens se voorstel vir só 'n stelsel is ander voorstelle ook oor verskeie jare gemaak (sien byvoorbeeld Naughtin, S.a.), maar nooit tot uitvoer gebring nie.

Die moderne metrieke stelsel het sy oorsprong uit die Franse Revolusie, en staan bekend as die International System of Units, afgekort as SI (na die Franse Système International d'Unités). Die metrieke stelsel is in Frankryk ontwikkel en in 1795 in gebruik gestel. Tydens die Metrisasiekonvensie in Parys in $1875^{2}$ is die International Bureau of Weights and Measures (Bureau international des poids et mesures, BIPM) opgerig, met die doel om "wêreldwye vereniging van metings" te verseker (BIPM, 2019:117).

Die SI bevat sewe basiseenhede wat gedefinieer word in terme van 'n stel van sewe fisiese konstantes, o.a. tyd (sekonde), lengte (meter) en massa (kilogram). Hierdie konstantes en basiseenhede is afgelei uit beginsels uit die fisiese en natuurwetenskappe, in teenstelling met argaïese instrumente wat kan vervorm of verlore gaan, of ongelyke fisiese eenhede soos duime, hande en voete.

Ander metrieke eenhede kan direk van hierdie konstantes en basiseenhede afgelei word. Sodanige "afgeleide" eenhede sluit bv. frekwensie (hertz, Hz), krag (force) (newton, $\mathrm{N}$ ), of energie (joule, J) in (BIPM, 2019:137). SI-eenhede kan voorts maklik in desimale eenhede vermenigvuldig of onderverdeel word. 'n Groot voordeel van die metrieke stelsel is dus juis hierdie konstante en gestandaardiseerde basiseenhede wat maklik vermenigvuldig of verdeel kan word om steeds konstante eenhede op te lewer. So kan 'n meter na bv. kilometer (1 000 meter) of millimeter (een duisendste van 'n meter) omgeskakel word, terwyl 1 minuut gelykstaande is aan 60 sekondes, ensovoorts. ' $n$ Verdere voordeel van die SI is dat daar eenvoudige verbande tussen verskillende eenhede bestaan wat nie die geval by ander stelsels is nie. ' $n$ Volume van 1 liter suiwer water het byvoorbeeld ' $\mathrm{n}$ massa van $1 \mathrm{~kg}$ en digtheid van $1 \mathrm{~kg}$ per liter $(1 \mathrm{~kg} / \mathrm{l})$. Sulke eenvoudige verbande is veral voordelig vir wetenskaplike berekenings, tegnologiese gebruike en ook om 'n konseptuele aanvoeling vir die eenhede te verkry.

In Frankryk is 'n "desimale kalender" (bekend as die "revolusionêre kalender") ook in 1795 aanvaar en tot 1805 gebruik (Zerubavel, 1977:860). Hierdie sekulêre kalender is onder meer in reaksie op kerklike oorheersing aanvaar. Die kalender het onder meer uit 10 dae per week bestaan, met
30 dae in elkeen van die 12 maande. Na 12 maande (360 dae) is vyf dae (ses dae in 'n skrikkeljaar) as "komplementêre dae" of "vakansiedae" (Sansculottides) bygevoeg om 'n jaar van 365 dae te verseker. Hierdie kalender het nie algemene byval gevind nie en is teen 1805 laat vaar (Zerubavel, 1977:860).

Die aanvaarding van die metrieke stelsel in Frankryk het ' $n$ rimpeleffek op die Europese vasteland tot gevolg gehad, en is sedertdien deur feitlik alle lande wêreldwyd in gebruik geneem. Die behoefte vir die gebruik van ' $n$ gestandaardiseerde internasionale stelsel het ontstaan uit toenemende internasionale handel, asook oorgrens (cross border) vervaardigingsprosesse. Die toenemende gebruik van die metrieke stelsel het gevolglik meer en meer lande genoop om die stelsel te aanvaar, onder meer ten einde internasionale handel en vervaardiging te vergemaklik.

Aldus Vera (2011) was daar in 2010 slegs sewe lande, insluitend die Verenigde State van Amerika (VSA) ${ }^{3}$ en sy geassosieërde lande, wat nié die metrieke stelsel aangeneem het nie. Teen 2020 gebruik slegs die VSA, Myanmar en Liberië nie amptelik die metrieke stelsel nie (Wêreldatlas, 2020). Verskeie lande het ook die stelsel amptelik aangeneem, maar hetmetrisering nog nievolledig geïmplementeer nie, soos in Afdeling 4 hieronder verder bespreek word.

\section{Suid-Afrikaanse geskiedenis}

Die eerste formele vasstelling van meetinstrumente in Suid-Afrika is in 1681 deur die VOC aan die Kaap afgekondig, met die aanvaarding van die "Statuten van India" (Weights and Measures in South Africa, S.a.). Deur die "Statuten" is sekere meetinstrumente in die Kaap in gebruik geneem wat nie enige ekwivalent in die imperiale stelsel gehad het nie, byvoorbeeld:

1 Kaapse voet $=1,033$ imperiale voet

1 Lêer $=127$ imperiale gelling

Die mates en gewigte wat in die 17de en 18de eeu in SuidAfrika in die ou Kaapkolonie gebruik is was egter nie gestandaardiseer nie, met die effek dat daar beduidende afwykings in veral landopmetings was (Zakiewicz, 2011). Aangesien daar op daardie stadium nie 'n akkurate plaaslike verwysingsstandaard na die "oorspronklike" Rhynland voet (ook bekend as die Rijnlandse roede) was nie, is die Rhynland voet soos gebruik in die Kaap (bekend as Kaapse voet) gelyk aan 1,033 Engelse voet gestel (Zakiewicz, 2011). Die imperiale stelsel is in 1922 amptelik in Suid-Afrika aangeneem (Cardarelli, 2003), en vir die volgende sowat 50 jaar gebruik. Met die uitsondering van Natal (vandag KwaZulu-Natal), is Kaapse voet vóór metrisering vir landmetingsdoeleindes in Suid-Afrika gebruik, ten spyte van die algemene aanvaarding van die imperiale stelsel. 


\section{Omskakeling in Suid-Afrika}

Die uiteindelike aanvaarding van ' $n$ metrieke stelsel vir Suid-Afrika kan tot WO II en die tydperk onmiddellik na die oorlog teruggevoer word (Arndt, 1961). Erasmus (1960:277) verklaar dat Suid-Afrika se Raad van Handel en Nywerheid die kwessie van na-oorlogse heraanpassing van nywerhede en ekonomiese heropbou in die algemeen ondersoek het. In hierdie ondersoek het die Raad " ... teenoor die kwessie van standaardisering te staan gekom ... (met) ... hoofbelangstelling mate en gewigte". Die Raad het aanbeveel dat " ... die Regering, tesame met die Regerings van die Britse Gemenebes en die Verenigde State van Amerika, die invoering van die metrieke muntstelsel, gewigte en mate in oorweging neem" (Erasmus, 1960:277; sien ook Chalupsky et al., 1974:49).

Die Nasionale Bewarings- en Antiverkwistingsorganisasie, 'n organisasie wat tydens WO II in die lewe geroep is om verkwisting te bekamp en sodoende die oorlogspoging te ondersteun, het in 1944 by die verantwoordelike Minister ${ }^{4}$ aanbeveel dat "... die menings van verteenwoordigende openbare liggame in die Unie oor die moontlikheid van desimalisering van ons geldstelsel, mate en gewigte ingewin moet word" (Erasmus, 1960:277). In reaksie op hierdie aanbeveling het Minister Hofmeyr die Becklakekomitee benoem om metrisering en desimalisasie te ondersoek. Die Becklakekomitee het teen 1948 verslag gedoen en ten gunste van die desimalisasie van die geldstelsel en mate en gewigte bevind (Erasmus, 1960:278). Die Komitee het egter ook aanbeveel "dat geen stappe in verband met die desimalisasie van Suid-Afrika se gewigte en mate" op daardie tydstip geneem moet word nie (Erasmus, 1960:278), maar dat optrede met betrekking tot metrisering tot praktiese vereenvoudiging en standaardisering beperk moet word. Die aanbeveling was baie duidelik dat die twee prosesse van metrisering en desimalisasie geskei moet word ten einde verwarring onder die publiek te beperk. Desimalisasie het dus voorkeur geniet. 'n Vroeë bekommernis was ook die moontlike negatiewe impak op handel met die VK en VSA, Suid-Afrika se groot handelsvennote wat nie gemetriseer het nie, indien Suid-Afrika vóór hierdie lande sou metriseer (Chalupsky et al., 1974).

Die Suid-Afrikaanse regering het in 1957 die Desimale Muntkommissie aangestel om die praktiese implementering van desimalisasie te ondersoek nadat reeds tevore besluit is dat Suid-Afrika sal desimaliseer. Suid-Afrika het op 14 Februarie 1961 'n desimale geldstelsel van rand en sent aanvaar. Voorheen is die stelsel van pond, sjielings en pennies $(£ / \mathrm{s} / \mathrm{d})$, gebruik. ${ }^{5}$ Die amptelike omskakelingskoers was $R 2,00=£ 1 /-/-$, terwyl die sjieling met 10 sent en die pennie met een sent vervang is (sien Rossouw, 2020). Een van die groot uitdagings in die desimalisasieproses was die omskakelingskoers tussen die ou en nuwe geldeenhede. Hierteenoor is die omskakelingskoerse van imperiale na metrieke volumes, mates en massaeenhede internasionaal gestandaardiseer en bloot later in SuidAfrika nagevolg. Suid-Afrika het die omskakelingstandaard van die internasionale SI-stelsel (Systeme International d'Unites) gebruik (Ball, 2016).

Na die suksesvolle afhandeling van desimalisasie kon metrisering aandag geniet. Chalupsky et al. (1974:49) verklaar dat:

A committee was appointed by the Council of the South African Bureau of Standards in 1962 to investigate the practicability and full implications of the adoption of the metric system of weights and measures. The committee came to the conclusion that the change to the metric system would facilitate the expansion of South Africa's foreign trade and that the internal efficiency of the country would be greatly increased.

Laner (1978) se interpretasie van die geskiedenis verskil van die interpretasie van Chalupsky et al. (1974). Laner (1978:4) verklaar dat Suid-Afrika se

\begin{abstract}
... Minister of Economic Affairs appointed T. H. Louw as Chairman of a study, similar to the U. S. Metric Study, undertaken from 1962 through 1964. The Louw Report polled segments of industry, commerce, and the various publics on the matter. Out of the respondents polled, some 67 per cent approved the move, and some 80 per cent indicated that no major problems would exist.
\end{abstract}

Die Suid-Afrikaanse regering het dus tot na desimalisasie in 1961 gewag voor die proses van metrisering aangevoer is. Soos in Suid-Afrika die geval was, het die meeste ander lande die omskakeling van desimalisasie en metrisering ook as twee afsonderlike prosesse hanteer. Teen daardie tyd het die meerderheid van Suid-Afrika se handelsvennootlande reeds die metrieke stelsel aangeneem, was besig met ' $n$ omskakelingsproses, of het in beginsel op omskakeling besluit (Ball, 2016, Vlietstra, S.a.). Die feit dat Suid-Afrika se vernaamste handelsvennoot op daardie tydstip - die VK - ook metrisering ernstig oorweeg het, het ook bygedra tot die wenslikheid dat die metrieke stelsel plaaslik aangeneem moet word (Chalupsky et al., 1974). Na die ondersoeke, soos deur Chalupsky et al. (1974) en Laner (1978) gerapporteer, se werksaamhede voltooi is, het die Suid-Afrikaanse regering in 1966 besluit dat die land die metrieke stelsel moet aanvaar (Chalupsky et al., 1974:49). Op 15 September 1967 is 'n Metrikasie-Adviesraad aangestel om Suid-Afrika se metrisering te beplan en te koördineer (Ball, 2016). Die Adviesraad het binne die SuidAfrikaanse Buro vir Standaarde gefunksioneer, met die Minister van Beplanning (adv J. J. Loots) as die verantwoordelike Minister.

Aldus Vlietstra (S.a.) is volumes en massa na die omskakeling slegs in metrieke standaarde op verpakkings aangedui, met verpakkings wat dieselfde grootte as tevore behou het. So is die massa van 'n produk wat een pond (16 onse) voor metrisering was, daarna bloot as 454 gram aangedui (Vlietstra, S.a.), Dit was 'n belangrike verskil van 
die praktyk 'n dekade tevore, toe pryse van produkte na desimalisasie vir ' $n$ tydperk in beide rand/sent en in $£ / \mathrm{s} / \mathrm{d}$ aangedui is (Rossouw, 2020). Kragtens die SI-stelsel is die volgende omskakelingskoerse onder meer gebruik (Simetric, S.a.):

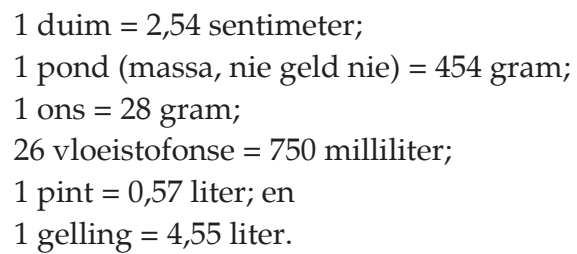

Vlietstra (S.a.) verduidelik dat metrisering deur daadwerklike stappe en optrede deur die Suid-Afrikaanse regering ondersteun is ten einde die proses so vinnig as moontlik tot uitvoer te bring. Dit verklaar die gebruik van slegs metrieke mates op produkte. Voorts het die regering 'n verbod geplaas op " ... measuring devices that were calibrated in imperial units ... and the media was forbidden to use imperial units" (Vlietstra, S.a., sien ook Ball, 2018) in verslagdoening na 1 April 1971. As verantwoordelike minister het adv. Loots dus 'n duidelike en leidende rol gespeel.

Chalupsky et al. (1974:53) stel dit selfs sterker as ander literatuurbronne:

South Africa's metric conversion program has been almost a model of precision scheduling, due to the fact that conversion steps have been largely made by Government decree. For example, a Government edict, published in late 1972, stated that as of 1 August 1973, it would be illegal for any retail merchant to sell certain non-metric measuring instruments and measures.

Metrisering is ondersteun deur ' $n$ publisiteitsveldtog, soos ook met desimalisasie die geval was (Rossouw, 2020). Chalupsky et al. (1974:53) verklaar dat verskeie inligtingspamflette en tegniese nuusbriewe oor aspekte van metrisering versprei is, terwyl die SA Buro van Standaarde 'n maandelikse nuusbrief, African Metrication News, gepubliseer het. Die oogmerk van die publisiteitsprogram was om die publiek touwys in metrieke mates, massaeenhede en volumes te maak sodat die nuwe standaarde so spoedig doenlik in die algemene omgang aanvaar sou word (Chalupsky et al., 1974:53).

Metrisering is ook daadkragtig by skole en universiteite ingevoer. Die regering het opvoedkundige instansies verplig om slegs die metrieke stelsel in die klasomgewing te gebruik. Ook in skolesport het wedlope soos die $100 \mathrm{~m}$ die 100-treë naelloop vervang. Kinders het dus van jongs af die metrieke eenhede leer ken. Verder is afstandbordjies langs die grootpad wat in myl was vervang om afstande alleenlik in kilometers aan te dui. Daar is ook elke $1 \mathrm{~km}$ langs die pad stene geplaas wat die reisigers 'n gevoel vir die kilometer-afstand gegee het. ${ }^{6}$

Vlietstra (S.a) se oordeel is dat die Suid-Afrikaanse bevolking metrisering sonder teenstand aanvaar het en daarby aangepas het weens die gerief van die metrieke stelsel. Metrisering kan ook gesien word as ' $n$ minder komplekse omskakeling as desimalisering, aangesien die metrieke stelsel op daardie tydstip internasionaal reeds wyd in gebruik was (Velkar, 2020). Verder het die feit dat Suid-Afrika kort voor metrisering 'n soortgelyke omskakeling (desimalisasie) ondergaan het waarskynlik ook bygedra tot ' $n$ relatief soomlose en volledige metrisering.

Suid-Afrika het in 1973 die Wet op Meeteenhede en Nasionale Meetstandaarde (Wet No. 76 van 1973) aanvaar (Zakiewicz, 2011). Die Metrikasie-Adviesraad het gevolglik teen 1977 ontbind omdat metrisering afgehandel was (Ball, 2018). In vergelyking met metrisering in ander lande wat hieronder bespreek word, het Suid-Afrika die proses vinnig en suksesvol afgehandel. Na die ontbinding van die Raad is die beperkings wat vir die aanduiding van imperiale mates gegeld het, en op die wat vir die media van toepassing was, opgehef (Vlietstra S.a.). Teen daardie tyd was daar egter geen rede meer om na enige van die vorige stelsels te verwys nie. Chalupsky et al. (1974:53) se bevinding is dat

The cornerstones of the metric conversion in South Africa are known as the four " $c$ 's" of conversion - consultation, cooperation, coordination and communication ... In comparison to other countries' approaches one might well add a fifth " $\mathrm{c}$ " here - compulsion.

Laner (1978:1) is van mening dat

the Republic of South Africa ... represents an outstanding example of a country that has made unprecedented and enviable progress in moving from the outdated English (Imperial) Units to the International Units. The achievements in this program are even beyond what the original metric countries of Europe have been able to do to date.

Suid-Afrika se omskakeling was dus suksesvol omdat die land voldoen het aan die vyf " $\mathrm{C}^{\prime} \mathrm{s}$ " (consultation" ${ }^{7}$ cooperation $^{8}$, coordination ${ }^{9}$, communication ${ }^{10}$ en compulsion ${ }^{11}$ ) wat Chalupsky et al. (1974) vir sukses identifiseer. Terselfdertyd het Suid-Afrika ook Chalupsky et al. (1974) se voorvereisdes vir suksesvolle omskakeling toegepas, naamlik (i) grootskaalse gemeenskapsbetrokkendheid, (ii) regeringsverbintenis tot beleidsbesluite en vaste tydskedules, en (iii) deurlopende kommunikasie en koördinasie vanaf owerheidsweë.

Hoewel Suid-Afrika metrisering volledig voltooi het, word 'n kombinasie van metrieke en imperiale mates steeds vir sekere items gebruik, in ooreenstemming met soortgelyke internasionale gebruike. Suid-Afrika volg hierdie praktyk

\footnotetext{
6 Ons is dank verskuldig aan ' $n$ anonieme eweknie-beoordelaar wat addisionele praktiese voorbeelde van staatsondersteuning vir die metriseringsproses voorgestel het. Vertaal as konsultasie. 
omdat dit die internasionale standaard in alle lande is, ongeag van die betrokke land se gebruik van die imperiale of metrieke stelsel van mates en gewigte. Hierdie aspek is gevolglik buite Suid-Afrikaanse beheer. ' $n$ Bekende voorbeeld is voertuigbande. Die wydte van die loopvlak word in metrieke mate (millimeters) aangedui en die profiel van die band word as persentasie van die loopvlak aangedui, ook in millimeter. Die vellinggrootte word daarenteen in imperiale mate (duim) aangedui. 'n Praktiese voorbeeld sou wees die bandgrootte 205/65/17, met 'n loopvlakwydte van 205 millimeter, 'n profiel van 133,25 millimeter (65 persent van $205 \mathrm{~mm}$ ) en 'n vellinggrootte van 17 duim. 'n Verdere voorbeeld is die wydte van tablet-, rekenaar- en televisieskerms, wat in imperiale mates (diagonaal in duim) aangedui word, terwyl ander spesifikasies in metrieke mates aangedui word. 'n Ander voorbeeld is die internasionale goud- en platinumpryse, wat per ons verhandel. Suid-Afrika is 'n uitvoerder van goud en platinum, wat op die internasionale mark verkoop word.

Voorts is die gebruik van die desimale komma problematies. Dit is nie so wyd aanvaar soos ander metrieke mates nie. Een rede vir die gemengde gebruik van die desimale komma en die desimale punt is die feit dat rekenaarprogramme soos Excel desimale punte gebruik, eerder as kommas.

Suid-Afrika het 'n doelbewuste en "onmiddellike" strategie gevolg om vir alle praktiese doeleindes volledige metrisering te bereik. Oor die langer termyn is dit voordelig, soos blyk uit die feit dit teen 1977 reeds nie langer nodig was om na imperiale mates te verwys nie en dat geen beheermaatreëls na daardie datum nodig was nie. Die suksesvolle implementering het besparing op die langtermyn tot gevolg. Adv. Loots as verantwoordelike minister en die Suid-Afrikaanse regering het dus op die korrekte strategie besluit.

Chalupsky et al. (1974:114) het in 'n meningsopname oor metrisering onder Suid-Afrikaners bevind dat "respondents in South Africa showed little inclination to do things differently - except to have converted 50 years ago. Most reported they felt things had gone as well as one could reasonably hope". Laner (1978:1) beskryf metrisering in Suid-Afrika "as an outstanding example" van sukses, selfs in vergelyking met metriseringsprosesse in sekere Europese lande.

\section{Metriseringsprobleme in sekere ander lande}

Hierdie afdeling belig lande wat metrisering onvolledig (gedeeltelik) of glad nie deurgevoer het nie. Die situasie in Suid-Afrika en die sukses wat plaaslik behaal is word spesifiek vergelyk met die toedrag van sake in die VK en die VSA in die lig van die destydse aanbeveling van die Raad van Handel en Nywerheid dat " ... die Regering, tesame met die Regerings van die Britse Gemenebes en die Verenigde State van Amerika, die invoering van die metrieke muntstelsel, gewigte en mate in oorweging neem" (Erasmus, 1960; sien ook Chalupsky et al., 1974:49). Met die uitsondering van die VK, het alle Gemenebeslande sedertdien metrisering suksesvol ingevoer, terwyl die VSA egter nie metrisering aanvaar het nie.

\section{Nie-gemetriseerde lande}

Daar is vandag slegs drie lande wêreldwyd wat nie amptelik die metrieke stelsel aangeneem het nie. Die VSA het nooit gemetriseer nie, ten spyte van die Metric Conversion Act van 1975 wat die metrieke stelsel die "voorkeur"stelsel $^{12}$ in die VSA gemaak het (Wêreldatlas, 2020). Die Metrieke Raad is ook in die VSA gestig om die metriseringsproses te koördineer. Anders as in Suid-Afrika en verskeie ander lande is die metrieke stelsel egter nooit in die VSA verpligtend gemaak nie. Verder het die Metric Conversion Act geen teikendatums vir die afhandeling van metrisering gestel nie, met die gevolg dat die metriseringsproses vinnig stoom verloor het. Die Metrieke Raad is gevolglik in 1982 ontbind (NIST, S.a.). Desnieteenstaande die feit dat metrisering sedertdien sonder oortuiging voortgeploeter het, is daar tog areas waar metrieke mates wel in die VSA gebruik word (TIME, 2019; NIST, S.a.), soos byvoorbeeld gemengde gebruik in die geval van motorbande. Dit is egter duidelik dat daar nie die politieke wilskrag was om die metriseringsproses streng te implementeer nie; tesame met die vrywillige aanneming van metrieke mates was daar gevolglik geen druk of dwang om die stelsel aan te neem nie.

Die Myanmarse Handelsministerie het die kilogram in 2011 voorgestel as basiese handelseenheid (MM Times, 2011). Ten spyte van hierdie voorgenome eerste stap na die metrieke stelsel, gebruik Myanmar vandag steeds 'n kombinasie van tradisionele Burmese, Imperiale en metrieke mates. Liberië het ook nooit gemetriseer nie. 'n Informele kombinasie van gebruiklike (tradisionele) eenhede en metrieke mates word gebruik. Die Liberiese regering het in 2018 aangekondig dat hulle beplan om die metrieke stelsel aan te neem om handel te vergemaklik (Liberian Observer, 2018).

\section{Gedeeltelike metrisering}

Die volgende 13 lande het metrisering amptelik aangeneem maar net gedeeltelik voltooi: Die VK, Noord-Korea, Chile, Peru, Thailand, Sjina, Indonesië, Sri Lanka, Macau, Taiwan, Hong Kong, die Fillipyne en Jamaika. ${ }^{13}$ Die redes vir onvolledige metrisering in die VK bied ' $n$ interessante kontras met Suid-Afrika se ondervinding.

12 Hierdie wet het die metrieke stelsel daargestel as "the preferred system of weights and measures for US trade and commerce" (USMA, S.a, eie beklemtoning)

13 Ten spyte van volledige metrisering in sekere lande, word enkele imperiale mates steeds vir historiese redes gebruik. ' $n$ Bekende voorbeeld is die gebruik van die imperiale pint $(568 \mathrm{ml})$ vir bierverkope in kroeë in die lerse Republiek. Die uitdrukking "glass of beer" word algemeen gebruik vir ' $\mathrm{n}$ half-pint (284 ml) bier. Natuurlik geld dieselfde ten opsigte van items soos motorbande en skerms ook in gemetriseerde lande, soos in Suid-Afrika die geval is. 
Terwyl die Europese vasteland reeds teen die einde van die $19^{\text {de }}$ eeu volledig gemetriseer was, het metrisering in die VK eers in 1965 formeel afgeskop met die aankondiging van 'n vrywillige metriseringsprogram. 'n Metrikasieraad is ook in 1969 geskep, en die mikpunt is gestel dat metrisering teen 1975 afgehandel sou wees. 'n Belangrike doelstelling van hierdie program was die VK se beplande toetrede tot die Europese Ekonomiese Gemeenskap (EEK) $)^{14}$ en harmonisering met Europa om internasionale handel te bevorder. Daar was egter politieke teenstand teen verdere Europese integrasie, ${ }^{15}$ wat neerslag in die metriseringsveldtog gevind het (Velkar, 2020). Die industriële sektor was ten gunste van ' $n$ volledige - en verpligte - metrisering, terwyl verskeie politici 'n pro-"vrye keuse"-veldtog gevoer het. Toenemende Euroskeptisisme gedurende die 1970s ${ }^{16}$, tesame met louwarm staatsbestuur van die projek, het egter daartoe gelei dat die VK se metriseringsprogram teen 1979 laat vaar is (Velkar, 2020). Dit ten spyte daarvan dat anders as die VSA - die VK die metrieke stelsel as amptelike stelsel in 1965 aangekondig het. Chalupsky et al. (1974:53) vergelyk metrisering in Australië met die VK soos volg:

The fact that the (Australian) government has taken a lead role (in metrication) has apparently had a positive effect upon the country. This contrasts rather sharply with the English situation. There the government initially tended to remain aloof ...

'n Verdere komplikasie was moontlik dat die VK terselfdertyd die geldeenheid gedesimaliseer het. ${ }^{17}$ Desimalisering was gesien as belangriker as metrisering, en het gevolglik breër ondersteuning geniet (Velkar, 2020). Die hoë inflasie van die vroeë-1970s is ook gedeeltelik op desimalisasie en metrisering geblameer (Alt, 1979), wat enige oorblywende welwillendheid teenoor die metriseringsveldtog laat verdwyn het. Aldus Velkar (2020:562) het die "staking van verpligte standaardisering in 1979" die "relatiewe onmededingendheid van Britse industrie" in hierdie tydperk vererger. Gelyktydige metrisering en desimalisasie in die VK is egter ' $n$ aspek wat Chalupsky et al. (1974) nie as 'n probleem geïdentifiseer het nie.

\section{Gemeenskaplike faktore m.b.t. onvolledige metrisering}

Die ervaring van die VSA (as ongemetriseerd) en die VK (as gedeeltelik gemetriseer) kan met Suid-Afrika (volledig gemetriseer) vergelyk word. Beoordeel aan die standaarde en voorvereistes wat Chalupsky et al. (1974) vir sukses identifiseer, het die VK sowel as die VSA soos volg te kort geskiet in pogings om metrisering volledig deur te voer:

(i) Gebrekkige politieke leierskap. Nóg die Amerikaanse nóg die Britse regering het metrisering met oortuiging nagestreef. (ii) In beide lande was daar politieke teenkanting teen metrisering. Velkar (2020: 562) belig die "vyandigheid teenoor metrisering" in sowel die VK as die VSA.

(iii) Gebrekkige bestuur van owerheidsweë. Velkar (2020:564) betreur die VK se "deurmekaar en oneffektiewe" bestuur van die metriseringsproses, veral tydens $1965-1980$.

(iv) Onvoldoende dwang. Metrisering is aan die vrywillige aanvaarding van die publiek oorgelaat as "voorkeurstelsel". Dit was natuurlik egter makliker vir die Amerikaanse en Britse publiek om eenvoudig by die bekendheid en gemak van die imperiale stelsel te hou.

(v) Metriserings- en desimalisasieprosesse wat oorvleuel. Die VK het tegelykertyd probeer desimaliseer en metriseer. Die VSA het reeds in die $18^{\text {de }}$ eeu gedesimaliseer (Erasmus, 1960).

Hierteenoor het Suid-Afrika 'n streng benadering gevolg: Metrisering is verpligtend gemaak en die omskakeling is meedoënloos deur die regering gedryf. Die gebruik van imperiale mates is selfs wetlik verbied. Suid-Afrika het doelbewus eers desimalisering afgehandel voor metrisering verder aangeroer is. Hierdie doelbewuste ontkoppeling, maar ook die feit dat die twee prosesse kort na mekaar plaasgevind het, het die bevolking se aanvaarding en steun verseker en die oorgang vergemaklik.

Laastens het Suid-Afrika metrisering onafhanklik aangepak en deurgevoer. Suid-Afrika was nie ten tye van metrisering lid van die Gemenebes ${ }^{18}$ van lande nie. Alhoewel die VK en VSA ten tye van metrisasie Suid-Afrika se vernaamste handelsvennote was - en Suid-Afrika se omskakeling na metrieke mates dus nie sonder teenstand was nie (Chalupsky et al. 1974) - het die feit dat nóg die VK nóg die VSA gemetriseer het nie die Suid-Afrikaanse metriseringsproses gekortwiek nie. Die gevolg hiervan is heel moontlik datSuid-Afrika sehandel met ander gemetriseerde lande sterk gegroei het.

\section{Gevolgtrekkings}

Die ontleding in hierdie artikel toon dat Suid-Afrika metrisering suksesvol deurgevoer het, hoewel sekere anomalieë ten opsigte van sekere internasionale gebruike en praktyke steeds voorkom. Suid-Afrika het voldoen aan die vereistes wat Chalupsky et al. (1974:116-122) stel, naamlik gemeenskapsbetrokkendheid, duidelike regeringsbesluite en vaste tydskedules, en deurlopende kommunikasie en koördinasie deur die regering. Die regering het verskillende kombinasies van konsultasie, samewerking, koördinasie, kommunikasie en dwang gebruik

\footnotetext{
14 Die EEK het ook bekendgestaan as die Europese Gemenemark (Common Market). Die VK het in 1973 tot die EEK toegetree.

15 Sodanige pro-nasionalistiese en anti-integrasie retoriek was natuurlik nie net tot die VK beperk nie.

16 Dit herinner aan die latere uittrede van die VK uit die Europese Unie (Brexit).

17 Die Britse pond is op 15 Februarie 1971 gedesimaliseer.

18 Suid-Afrika het met Republiekwording in 1961 van die Gemenebes onttrek, en is in 1994 hertoegelaat.
} 
om die uiteindelike oogmerk, naamlik volledige metrisering binne die kortste moontlike tyd, te bereik. Vir hierdie politieke leiding verdien die verantwoordelike minister, adv. J. J. Loots, en die Suid-Afrikaanse regering krediet. Voorts het Suid-Afrika die slaggat van gelyktydige metrisering en desimalisasie vermy.

In teenstelling met metrisering in Suid-Afrika, het die proses in 13 ander lande skeefgeloop in die mate dat metrisering nie volledig geïmplementeer is nie. Verskeie faktore het in hierdie lande tot onvolledige metrisering bygedra. Dit sluit in aspekte soos:

(i) Gebrekkigepolitiekeleierskapenowerheidsbestuur;

(ii) Politieke teenkanting teen metrisering;

(iii) Onvoldoende dwang; en

(iv) Metrisering- en desimalisasieprosesse wat oorvleuel.

Hierdie aspekte is deurlopend vanaf owerheidsweë in die geval van Suid-Afrika bestuur. Die afwesigheid van die politieke wil om die metriseringsproses aan te dryf is potensieel die grootste tekortkoming in lande wat nie suksesvol gemetriseer het nie. Met 'n terugblik 50 jaar later, moet Suid-Afrikaners dankbaar wees vir streng regeringsbestuur om die proses te voltooi. Die koste van halfhartige en onvoltooide metrisering is onberekenbaar groot.

\section{Bibliografie}

Alt, J. E., 1979. The politics of economic decline: economic management and political behaviour in Britian Since 1964. CUP Archive.

Arndt, E. H. D. 1961. The introduction of a decimal coinage system in the Union of South Africa. South African Journal of Economics. June. Vol 29:2. https://doi. org/10.1111/j.1813-6982.1961.tb02359.x.

Asia-Pacific Legal Metrology Forum (APLMF). S.a. [Aanlyn] DPR Korea. https://www. aplmf.org/dpr-korea.html [Internettoegang op verskeie datums.]

Ball, P. 2016. A short history of the metrification movement in South Africa. Theheritageportal. 4 September. http://www.theheritageportal.co.za/article/ short-history-metrication-movement-south-africa [Internettoegang op verskeie datums]

Ball, P. 2018. Was there life before Metrication? Theheritageportal. 21 Julie. http://www.theheritageportal.co.za/article/was-there-life-metrication [Internettoegang op 23 Julie 2020].

Cardarelli, F. 2003. Encyclopaedia of Scientific units, weights and measures: their SI equivalences and origins. Springer Science \& Business Media. https://doi.org/10.1007/978-1-4471-0003-4.

Chalupsky, A. B., Crawford, J. J. and Carr, E. M. 1974. Final report: Going Metric - An Aanalysis of Experiences in Five Nations and Their Implications for U.S. Educational Planning. National Institute of Education Project No 3-2173. American Institutes for Research in the Behavioral Sciences. Palo Alto: California. https://files.eric.ed.gov/fulltext/ED104725.pdf [Internettoegang op 23 Julie 2020].
Erasmus, D. P. 1960. Die aanleiding tot en enkele implikasies van die desimalisasie van die Suid-Afrikaanse geldstelsel. Koers. Vol 27:10. https://doi.org/10.4102/ koers.v27i10.2078.

Hosch, W. L. (red.). 2010. The Britannica Guide to Numbers and Measurement (Math Explained). Britannica Educational Pub.

International Bureau of Weights and Measures (BIPM). 2019. The International System of Units (SI), 9de uitgawe. https://www.bipm.org/utils/common/pdf/ si-brochure/SI-Brochure-9-EN.pdf. [Internettoegang op 11 Augustus 2020].

Laner, F. J. 1978. Report on metric study tour to Republic of South Africa. Rockwell International, Colorado. https://doi.org/10.2172/5206656

Liberian Observer. 2018. Gov't Pledges Commitment to Adopt Metric System (25 May). https://www.liberianobserver.com/business/govt-pledgescommitment-to-adopt-metric-system/ [Internettoegang op verskeie datums].

Mackey, T. C. and Roodt, L. de V. 2002. Speed - is it relevant? Paper presented at the 21st Annual South African Transport Conference, South Africa. $15-19$ July. https://repository.up.ac.za/bitstream/handle/2263/7700/011.pdf?sequence [Internettoegang op 23 November 2020].

Naughtin, P. [S.a.] Commentary on John Wilkins' 'Of Measure.' Aanlyn by http:// www.metricationmatters.com/docs/CommentaryOnWilkinsOfMeasure.pdf [Internettoegang op 20 Oktober 2020].

National Institute of Standards and Technology (NIST). [S.a.] [Aanlyn]. The United States and the Metric System: A Capsule History. https://www.nist.gov/ system/files/documents/pml/wmd/metric/1136a.pdf [Internettoegang op verskeie datums]

Rossouw, J. 2020. Diamantjubileum van desimalisasie: 60 jaar van Suid-Afrikaanse rand en sent. Tydskrif vir Geesteswetenskappe. Vol 60:3, bl. 658-673. https://doi.org/10.17159/2224-7912/2020/v60n3a6.

Simetric. [S.a.] [Aanlyn] http://www.simetric.co.uk/feet_to_metres.php [Internettoegang op verskeie datums].

TIME. 2019. [Aanlyn] Why Won't America Go Metric? https://time.com/3633514/ why-wont-america-go-metric/ [Internettoegang op verskeie datums].

U.S. Metric Association (USMA). [S.a.] [Aanlyn] https://usma.org/laws-and-bills/ metric-conversion-act-of-1975\# [Internettoegang op verskeie datums].

Velkar, A. 2020. "Imperial Folly": metrication, euroskepticism, and popular politics in Britain, 1965-1980. The Journal of Modern History 92(3), 561-601. https:// doi.org/10.1086/710308.

Vera, H. 2011. The social life of measures: metrication in the United States and Mexico, 1789-2004. PhD-proefskrif. The New School for Social Research. https://pqdtopen.proquest.com/pubnum/3495843.html?FMT=A [Internettoegang op 11 Augustus 2020].

Verenigde Koninkryk (VK). 1824. An Act for ascertaining and establishing Uniformity of Weights and Measures. 17 Junie 1824. https://www.legislation.gov.uk/ ukpga/1824/74/pdfs/ukpga_18240074_en.pdf [Internettoegang op 11 Augustus 2020].

Vlietstra, M. [S.a.]. South African experience: Successful changeover in South Africa. UK Metric Association. https://ukma.org.uk/what-is-metric/southafrican-experience/ [Internettoegang op 23 Julie 2020].

Weights and Measures in South Africa. [S.a.]. Ancestors South Africa. https://www ancestors.co.za/weights-and-measures-in-south-africa/ [Internettoegang op 23 Julie 2020].

Wêreldatlas. 2020. Countries that don't actually use the metric system. https:// www.worldatlas.com/articles/countries-that-don-t-actually-use-the-metricsystem.html [Internettoegang op 17 Oktober 2020].

Zakiewicz, T. 2011. The South African measurement system and its origin. Position IT April/Mei 2011.

Zerubavel, E. 1977. The French Republican Calendar: A case study in the sociology of time. American Sociological Review. Vol. 42, No. 6. Desember. bl. 868-877. https://doi.org/10.2307/2094573. 